Article

\title{
How Much Water Can We Save by Achieving Renewable Portfolio Standards in the Southwest United States?
}

\author{
Yuzhen Feng ${ }^{1,2}$, Sachiko Sueki ${ }^{2}$, Dale Devitt ${ }^{1}$ and Kumud Acharya ${ }^{2, *}$ \\ 1 College of Sciences, University of Nevada, Las Vegas, NV 89154, USA; fe.yu.zh@gmail.com (Y.F.); \\ dale.devitt@unlv.edu (D.D.) \\ 2 Division of Hydrologic Sciences, Desert Research Institute, Las Vegas, NV 89119, USA; \\ sachiko.sueki@dri.edu \\ * Correspondence: kumud.acharya@dri.edu; Tel.: +1-702-862-5371
}

Received: 21 December 2017; Accepted: 11 March 2018; Published: 13 March 2018

\begin{abstract}
Electricity in the Southwestern United States is primarily generated with water intensive steam turbines. If energy demand continues to rise this will lead to a further rise in water demand. A comprehensive understanding of water consumption and withdrawal for utility scale generation of electricity is necessary before any improvements in the water efficiency of such systems in arid environments can be made. This study estimated and compared the water usage associated with thermoelectric generation (i.e., natural gas, coal), and solar energy, in the five driest Colorado River Basin states: Utah, New Mexico, Nevada, Arizona, and California. This study also examined and compared each state's Renewable Portfolio Standards (RPS) and how this might impact water savings. Results showed that each state's current RPS goals would reduce the water that is consumed by the generation of electricity. However, the amount of water savings will vary on a state by state basis. In order to reduce water consumption, replacing thermal electric generation with photovoltaic (PV) solar can be significant and should be encouraged. The amount of water saved will vary, however, depending on the state's choice of coal or natural gas.
\end{abstract}

Keywords: electric generation; water consumption; water withdraw; water usage; PV solar; thermoelectric; System Dynamic modeling

\section{Introduction}

Water plays a significant role in sustaining urban development as well as ecological activities. A majority of the flow in the Colorado River basin comes from Rocky Mountain snowmelt, yet most of the water usage occurs in the semi-arid and desert regions of the lower basin for irrigation and thermoelectricity $[1,2]$. Water usage also occurs in the domestic and industrial sectors, such as for processing sewage, manufacturing of goods, aquaculture, and mining. In recent years, due to below average snow pack, a continued decrease in water levels has been observed in reservoirs along the Colorado River. A vestige of the 139-year-old law, "use it or lose it" clause, which gives the farmers, ranchers and governments holding water rights a powerful incentive to use more water than they need, contributes to further water shortages [3]. In 2014, the initiative, known as the "System Conservation Pilot Program", which pays ranchers and farmers to let water run down the river instead of irrigating, started and proved popular. However, it was halted after three years until the officials work out challenges such as handling many participants and deciding the amount of compensation. The water law, "use it or lose it", also poses a hurdle to the program [4]. Water levels in Lake Powell and Lake Mead have dropped to less than $50 \%$ and $40 \%$ reservoir capacity, respectively. Diminishing discharges throughout the river basin have not only put pressure on human usage, but have also led to an 
increase in the number of endangered or threatened species [1]. The management of how we can balance water resources for urban development while maintaining viable desert ecosystems represents a significant challenge.

Increased drought severity will amplify wildfire frequencies in arid regions and the bordering regions [5]. Losses due to wildfires include not only wildlife habitats and their associated ecological activities, but also billions of dollars for fire management and damage control [6]. The increased risks of more frequent and mega-droughts in the Southwest indicates a need for the reevaluation of past water conservation plans and the need to prevent further water shortages.

Along with climate change, rapid urban development in the Southwest can also contribute to the water crisis. Based on the 2014 U.S. Census estimates four out of the top ten fastest-growing states in the nation are from the Southwest. These states are Nevada, Colorado, Arizona, and Utah ranked from highest to lowest [7]. The population in these states have increased at least 15 percent from 2005 to 2015. Rapid population growth has resulted in competition for water resources across different sectors. At the national level, for the past several decades, the largest portion of water withdrawal was for thermoelectric power production, followed by irrigation and public supply. In years prior to 2010, water withdrawal for thermoelectric production was 609 billion liters per day, which accounted for well over $45 \%$ of the national total [2]. The historic loss of reservoir storage has resulted in hydroelectric production losses and decreased energy supplies [8]. Production of electricity at Hoover Dam has been reduced by about 25 percent, whereas Glen Canyon Dam's power production has experienced an 8 percent annual drop based on the 2013-14 expectation $[9,10]$. In recent years Lake Shasta has dropped to half of its reservoir capacity, which has caused a cutback of approximately one third of the dam's production of electricity [11]. Many dams across California face the same situation and some are down to less than 20 percent of their normal production. These reductions in productions of hydroelectricity will have to be compensated by other energy sources, such as natural gas [12].

In the Southwest, various water conservation programs have been implemented, which target public and domestic water usage. Such programs include usage of reclaimed water on golf courses, incentives to promote adaptation to less water intensive landscapes, and reinforcing community-based watering schedules [13]. However, few were aimed towards the utility scale energy sectors even though the process of thermal energy production is highly dependent on water. Conventional methods of generating electricity are based on burning fossil fuels, such as coal or natural gas, which is commonly referred to as thermoelectric generation. Steam-run and combustion turbines are the two most commonly used thermoelectric technologies throughout the Southwest. In typical steam-run generating units, water is needed for a boiler to create steam to rotate the turbine blades, which drives the compressor to create energy. In combustion turbines, high-temperature gasses pass through a combustion chamber to achieve the same reactions, but a considerable drop in pressure is expected throughout the process. In order to capture potential heat loss, some power plants have heat recovery systems that boil water to drive a secondary steam turbine. Other water uses are needed in the operational phase, such as flue gas cleaning to reduce air pollution, removal of mineral build-up in cooling towers to increase cooling efficiency, and the cooling agent for various types of cooling systems. Furthermore, pre-operational procedures, such as fuel processing, transportation, and disposal can also contribute significantly to the total water withdrawal and consumption. Water withdrawal refers to the amount of water removed from a water body, but some of that water can be returned to its source. Whereas, water consumption refers to the amount of water removed that cannot be returned to its source. The term "water usage" includes both water withdrawal and water consumption from a water body. Although some renewable energy sources use less water than conventional nonrenewable thermoelectric systems, any type of thermal energy that employs steam turbine technology and cooling systems will consume significant amount of water [14].

Generation of electricity from renewable energy sources, such as solar, biomass, and geothermal energy can reduce the dependency of water in the generation process only if the power plant uses the most efficient cooling systems. The use of renewable energy such as solar and wind also alleviates 
the concern that fuel sources might eventually run out in the future. Factors such as reduced cost, innovative financing, and the abundance of sunlight in the Southwest have increased the popularity and demand for photovoltaic (PV) solar energy. Most of the thermoelectric water withdrawal in the Southwest comes from scarce surface waters in the reservoirs of the Colorado River basin and neighboring groundwater wells. Nevada currently has 20 out of 63 power facilities that use nonrenewable fossil fuels for energy generation. More than a third of these facilities still employ steam technologies that consume a massive amount of water each day [15]. The same trends are seen in the neighboring basin states, 37 out of 61 power facilities in Arizona, 28 out of 46 power facilities in New Mexico, and 32 out of 45 power facilities in Utah use natural gas, coal, and petroleum products for the generation of electricity. Current rates of implementing renewable production of electricity and water conservation strategies to preserve water resources are not keeping up with the growing water demands that are associated with the agricultural, industrial, and public sectors in the southwest. What little water data currently exists for power plants that are publicly accessible is not focused on the total water usage throughout the electricity production process. Past studies on the water usage per unit of electricity generated were conducted by $[14,16]$. However, they focused on only parts of the energy generation process. In addition, topics on efficient energy are highly publicized, yet the impact that electricity generation has on water resources are oftentimes overlooked. In this study, total water usage in the production of electricity in each Colorado River basin state; Nevada, Arizona, California, New Mexico, and Utah, was estimated. Furthermore, we estimated how water consumption is likely to change in the next ten to twenty years. Detailed estimations of the water used in energy production can offer insights into water resource management in the lower Colorado River Basin.

\section{Methods}

\subsection{Total Water Usage by Thermal and PV Solar Power Plants}

Total water usage in each basin state was calculated by summing the estimated water withdrawal and consumption of each generating unit at all thermal and PV solar plants. The water withdrawal or consumption of each generating unit was calculated by multiplying average water use coefficients with the estimated gross generation of electricity [17]. Where the water use coefficient is a conversion factor to estimate water usage from the amount of generated electricity by considering the types of fuel and generating facility. The water use coefficient includes pre-operational and operational water use. Pre-operational water use refers to the water that is used to acquire and prepare the fuel sources. Operational water use refers to the water withdrawal and consumption throughout the process of generating electricity. For instance, pre-operational water uses are water used for beneficiation, transportation, construction, fuel mining and extraction. Operational water uses include water used at processes like flue gas desulfurization and combustion turbine inlet cooling. Pre-operational and operational water coefficients were determined based on the past study by $[14,16,18]$ as shown in Tables 1-3. Pre-operational water use for PV solar electricity generation was considered to be zero because PV solar requires no water for fuel. Thermal energy production has high operational water use, regardless of the fuel source because of water necessity in steam production and cooling. Similarly, thermal-renewable energy sources, such as concentrated solar power (CSP), biomass, and geothermal technologies generate energy via steam turbines, which is similar to the use of fossil fuel that has high operational water use. On the other hand, PV solar plants use water mainly for panel maintenance and were considered as a no wet-cooling system [14]. Therefore, operational water use for PV solar plants is substantially lower than those of thermal energy plants.

The gross generation for each generating unit at thermal and PV solar power plants was estimated based on the publicly available utility scale power facilities' data collected from the Energy Information Administration (EIA) by the U.S. Department of Energy for years 2005 to 2015. These publicly available electricity data were self-reported to the EIA by power plants that met two criteria: (1) Power plants that have a nameplate capacity of one megawatt (MW) or greater; and (2) Power plants that have 
generators connected to the local or regional electric power grid and can draw or deliver power to the grid [19]. The EIA Form 923 reports the annual net energy generation per generating unit whereas EIA Form 860 contains the plant gross generation. Therefore, the gross generation per generating unit was estimated, as follows:

$$
\text { Gross generation per unit }=(\text { Gross generation per plant }) \times \frac{\text { Net generation per unit }}{\text { Net generation per plant }}
$$

Any generating units that contained a net zero or negative electricity generation were excluded from the calculation. Average $17 \%$ of the annually reported units had a net zero or negative electricity generation for the years 2005 to 2015. Generating units were grouped by their generating unit type, fuel type and cooling system type based on power plant characteristics reported in EIA Form 860 and information found via literature survey. Power plants that did not report any specified cooling characteristics were assumed to have the same cooling systems that were found in the company's public records. The analysis assumed that all of the generating units within the same power plant employ the same fuel type and would also use the same cooling system. Once the electricity generation data were queried, the annual pre-operational and operational water-use coefficients were assigned. The total water withdrawal or consumption was then calculated.

Table 1. Operational water withdrawal and consumption coefficients (reproduced from [14]).

\begin{tabular}{ccccc}
\hline \multirow{2}{*}{ Fuel Type } & \multirow{2}{*}{ Prime Mover } & \multirow{2}{*}{ Cooling Type } & \multicolumn{2}{c}{ Water Use Coefficients (L/MWh) } \\
\cline { 3 - 5 } & & & Consumption & Withdrawal \\
\hline \multirow{4}{*}{ Coal } & \multirow{3}{*}{ Steam } & Tower & 2601 & 3804 \\
& & Pond & 2063 & 46,277 \\
& & Dry Cooling & 159 & 4834 \\
\cline { 3 - 5 } & Combustion & Generic & 1783 & 2218 \\
\hline & & Tower & 1431 & 958 \\
& \multirow{4}{*}{ Combustion } & Once Through & 379 & 43,078 \\
& & Dry Cooling & 8 & 8 \\
\cline { 3 - 5 } Natural Gas & CHP & 8 & 8 \\
\cline { 3 - 5 } & \multirow{2}{*}{ Combined } & Dry Cooling & 8 & 8 \\
& Cycle & Once Through & 379 & 43,078 \\
& & Tower & 1431 & 1878 \\
\cline { 2 - 5 } & \multirow{3}{*}{ Steam } & Dry Cooling & 1287 & 8 \\
& & Once Through & 908 & 132,489 \\
& & Pond & 908 & 22,523 \\
\hline Solar-CSP & Steam & Tower & 3274 & 3274 \\
\hline Solar-PV & & N/A & 98 & 98 \\
\hline
\end{tabular}

Table 2. Preoperational water withdrawal coefficients for coal, petroleum, and natural gas power plants (L/MWh) (reproduced from $[16,18]$ ).

\begin{tabular}{|c|c|c|c|c|c|c|c|}
\hline Fuel Type & Stage & & On-Site & Up-Stream & Both & Ave. per Process & Total per Fuel Cycle \\
\hline \multirow{7}{*}{ Coal } & \multirow{4}{*}{ Mining } & Eastern underground & 189 & 507 & 697 & \multirow{4}{*}{250} & \multirow{7}{*}{432} \\
\hline & & Eastern surface & 38 & 148 & 148 & & \\
\hline & & Western surface & $\mathrm{N} / \mathrm{A}$ & 11 & 11 & & \\
\hline & & U.S. coal & 106 & $\mathrm{~N} / \mathrm{A}$ & 106 & & \\
\hline & Beneficiation & & 45 & 53 & 98 & 98 & \\
\hline & Transportation & Train & $\mathrm{N} / \mathrm{A}$ & 38 & 38 & 38 & \\
\hline & Construction & Coal power plant & N/A & 45 & 45 & 45 & \\
\hline \multirow{6}{*}{$\begin{array}{l}\text { Natural } \\
\text { Gas }\end{array}$} & & Onshore & 129 & 299 & 432 & \multirow[b]{2}{*}{216} & \multirow{6}{*}{1223} \\
\hline & Extraction & Offshore & 0.8 & 0.4 & 1.1 & & \\
\hline & Purification & & 64 & $\mathrm{~N} / \mathrm{A}$ & 64 & 64 & \\
\hline & Pipeline transportation & & 2 & 38 & 38 & 38 & \\
\hline & Storage-underground & & $\mathrm{N} / \mathrm{A}$ & 15 & 15 & 15 & \\
\hline & $\begin{array}{c}\text { Power plant } \\
\text { environmental control }\end{array}$ & & $\mathrm{N} / \mathrm{A}$ & 890 & 890 & 890 & \\
\hline
\end{tabular}

N/A = Not available. 
Table 3. Preoperational water consumption coefficients for coal, petroleum, and natural gas power plants (L/MWh) (reproduced from [16]).

\begin{tabular}{|c|c|c|c|c|c|}
\hline Fuel Type & Stages & & Reported Max & Ave. per Process & Total per Fuel Cycle \\
\hline \multirow{4}{*}{ Coal } & Mining & $\begin{array}{c}\text { Surface } \\
\text { Underground }\end{array}$ & $\begin{array}{c}53 \\
201\end{array}$ & 125 & \multirow{4}{*}{235} \\
\hline & Washing & & 64 & 64 & \\
\hline & Beneficiation & & 45 & 45 & \\
\hline & Transportation & Train & $\mathrm{N} / \mathrm{A}$ & $\mathrm{N} / \mathrm{A}$ & \\
\hline \multirow{4}{*}{ Natural Gas } & & Onshore & NG & NG & \multirow{4}{*}{53} \\
\hline & Extraction & Offshore & NG & NG & \\
\hline & Purification & & 57 & 57 & \\
\hline & Pipeline transportation & & 30 & 30 & \\
\hline
\end{tabular}

N/A = Not available; NG = Negligible.

\subsection{Future Water Usage}

Future water usage was studied using System Dynamic (SD) modeling, which allows determination of how systems change over time incorporating different aspects that are involved in the system. The model was built using SD software, STELLA ${ }^{\circledR}$, taking into account population growth, average household use of electricity, electricity retail sales, and the state-wide water usage per unit of electricity. The model projected electricity generation based on the population growth and trends in electricity usage and sales (Figure 1a-c). Then, the amount of electricity generation for each fuel type was determined using the projected electricity demand and state's renewable portfolio standards (RPS) (Figure 1d-g). Finally, the future water usage was estimated by multiplying the projected electricity generation for each fuel type with each state's consumption rate (Figure 2).

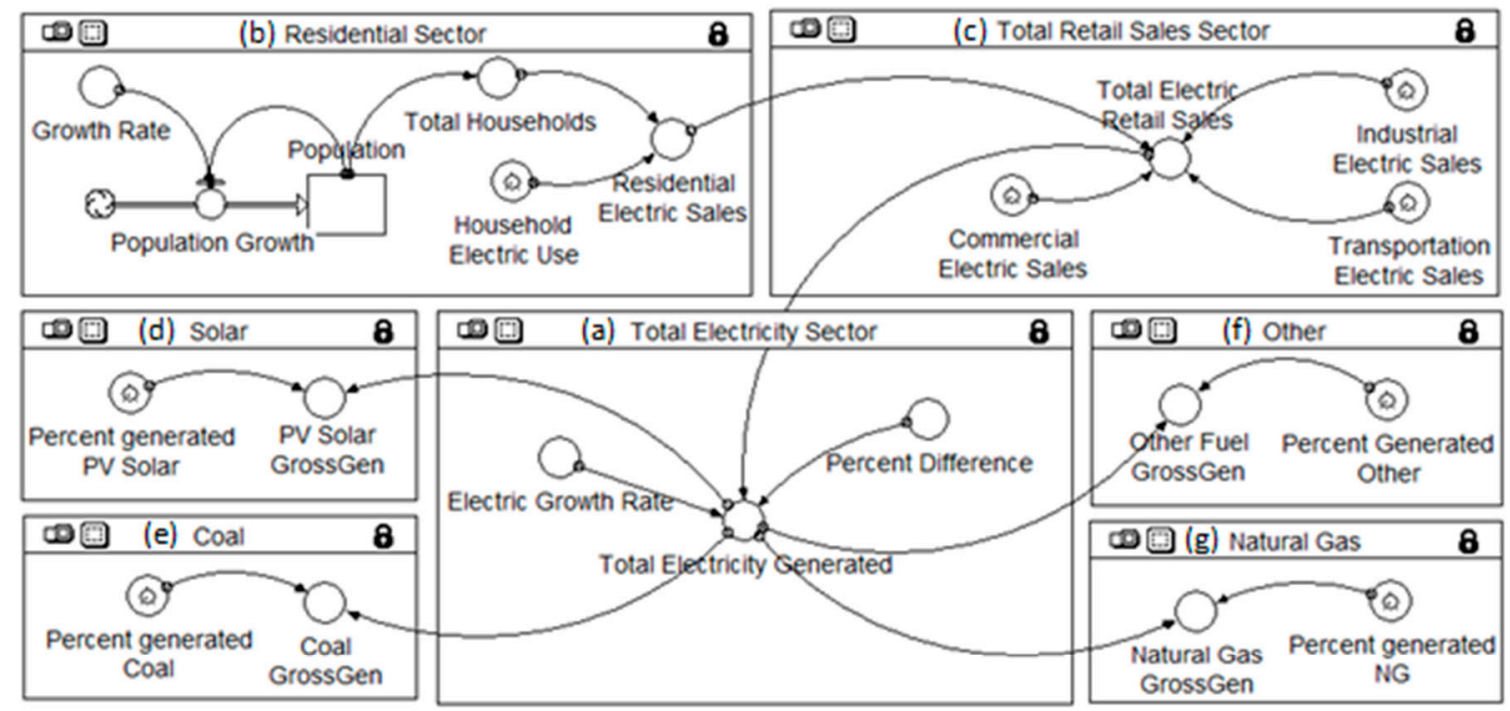

\section{: Accumulation}

() : Functions

Q Valued rate, which can be constant or change with respect to time or another component in the system

\section{Arrow represents transmission of information from one component to the next}

Figure 1. Schematic logical flow of total energy generation and its components in the developed model.

The projected electricity generation was estimated by projecting total electricity retail sales, which were categorized into four major groups: residential, industrial, commercial, and transportation. Residential sales were calculated by multiplying the total number of households and the average 
household electricity used, which was obtained from each state's local energy report assuming no significant changes in the future. The average household electricity used in Arizona, California, New Mexico, Nevada, and Utah were 12.7, 6.4, 7.9, 11.2, and 9.5 GWh/year, respectively. The projected number of households were estimated by dividing population by the average number of households between 2005 and 2014 in each state. The average number of households in Arizona, California, New Mexico, Nevada, and Utah were 2.69, 2.93, 2.63, 2.67, and 2.99, respectively. Population was projected from the average annual growth rate, which was calculated from the Census Bureau population data in each state [20]. The average annual growth rate of Arizona, California, New Mexico, Nevada, and Utah was $0.025,0.019,0.044,0.019$, and 0.019 , respectively. Electricity generation in the industrial, commercial, and transportation sectors did not correlate well with population (NS, $p>0.05$ ). Therefore, their sales were projected from the average percentage of the total electric sales from 2011 to 2014 , assuming that the percentage of each sector did not change significantly. Once the projected total electricity retail sales were obtained, the result was adjusted using a percent difference between total electricity sales and gross electricity generation estimated based on EIA's electricity annual forecasted growth rate of 0.9 percent per year [21].

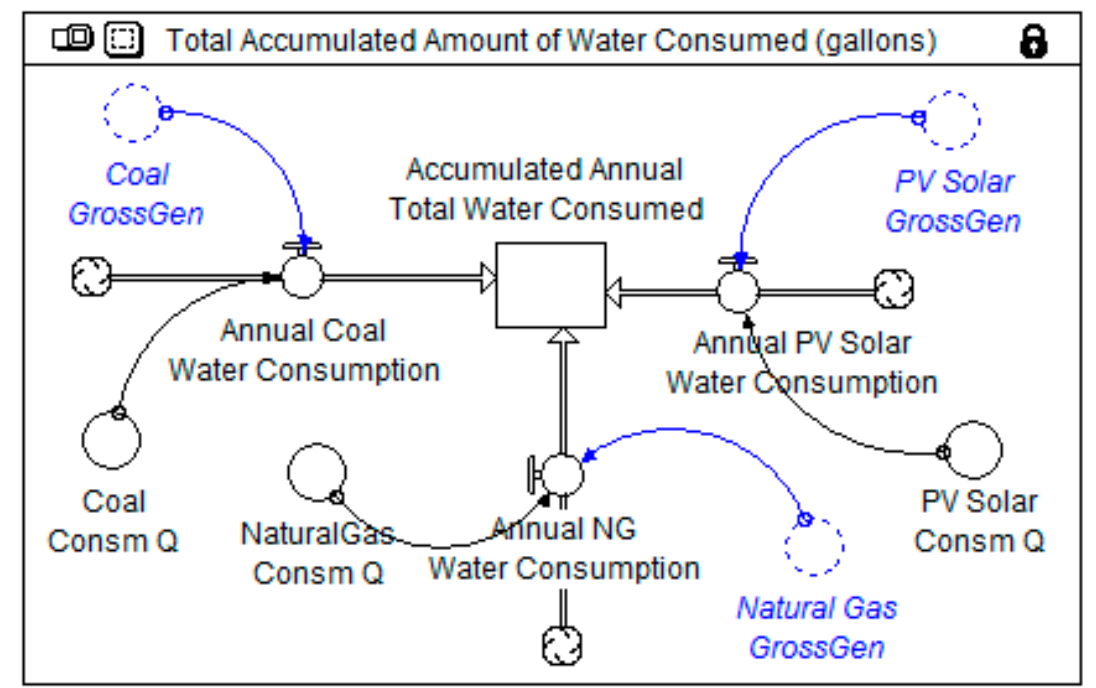

Figure 2. Schematic logical flow of water consumption. Definition of objects can be found in Figure 1.

The SD model considered four fuel types: PV solar, coal, natural gas, and others (such as geothermal, water, wind, and nuclear). The percentage of projected electricity generation for each fuel type was determined based on the limitations of each state's RPS program. Some common RPS regulation approaches are to increase various renewable energy sources, such as wind, solar, and other alternatives, while progressively decreasing the dependency on non-renewable fossil fuel electric generation such as coal or natural gas. Table 4 lists each state's RPS aims and the corresponding sources. For the purpose of this study, only the goals pertaining to PV solar are highlighted in the comparison among states.

In order to convert from electricity generation to water usage, a state specific consumption rate was calculated using the estimated state annual gross generation and average water consumption rate for each fuel type between 2005 and 2015, which is explained in the Section 2.1. For the purpose of this study, the water consumption rate was only calculated for coal, natural gas and PV solar. Therefore, the total water consumption estimated from the model included water consumption of three fuel types and assumed the percentage of the other fuel types remain relatively constant.

Note that, in the SD model, factors other than population growth that can affect the future water demand, such as regional climate changes, the duration of wet and dry years, and the generating unit characteristics (i.e., type of cooling system and type of technology) within each power plant were 
assumed to remain the same. Furthermore, the amount of electricity used would increase as population increases, assuming that population growth is at a higher rate than increase in energy efficiency.

Table 4. Expected implementation of renewable portfolio standards by state.

\begin{tabular}{|c|c|}
\hline Arizona [22] & $\begin{array}{l}\text { - Renewable energy to be increased to at least } 15 \% \text { by } 2025,30 \% \text { from distributed generation } \\
\text { (residential or non-utility owned) annual requirement }\end{array}$ \\
\hline California $[23,24]$ & $\begin{array}{l}\text { - To increase eligible renewable energy recourse to } 33 \% \text { by } 2020,50 \% \text { by } 2030 . \\
\text { - Mandated three large electric utilities to procure } 250 \mathrm{MW} \text { of Bioenergy generation } \\
\text { (such as biogas, organic waste, food processing, and co-digestion). }\end{array}$ \\
\hline New Mexico [25] & $\begin{array}{l}\text { - Total renewables to be increased to } 20 \% \text { by } 2020 \text {. } \\
\text { - Of which, no less than } 30 \% \text { ( } 30 \% \text { of the total } 20 \% \text { ) should be generated by wind, } 20 \% \text { by } \\
\text { Solar thermal/PV energy, } 5 \% \text { by other renewables, and } 3 \% \text { distributed generation. } \\
\text { (which translates to only } 6 \% \text { total in wind, and } 4 \% \text { total in solar, } 1 \% \text { in others, and } 0.6 \% \\
\text { from distributed generation) }\end{array}$ \\
\hline Nevada $[26,27]$ & $\begin{array}{l}\text { - Renewable energy to be increased every two years until it reaches } 25 \% \text { by year } 2025 \text {. } \\
\text { - } \quad \text { Of which, at least } 5 \%(5 \% \text { of the total } 25 \%) \text { must be generated by solar facilities by } 2015 \text {, } \\
\text { and } 6 \%(6 \% \text { of the } 25 \%) \text { must be generated by solar facilities for } 2016 \text { and beyond. } \\
\text { For years } 2016 \text { and after, } 6 \% \text { of that amount must be generated or acquired from solar } \\
\text { renewable energy systems. This translates to only } 1.5 \% \text { of the total electricity generated } \\
\text { from solar systems. } \\
\text { Retire or eliminate } 300 \mathrm{MW} \text { or more coal-fired electric generating capacity by } 2014 \text {, in } \\
\text { addition, eliminate } 250 \text { more MW by } 2017 \text {, and } 250 \text { more on top of the previous by } 2019 \text {. }\end{array}$ \\
\hline Utah [28] & "To the extent that it is cost-effective to do so", until then, at least 20\% starting 2025. \\
\hline
\end{tabular}

This study conducted two scenarios to simulate the projected energy outlooks by 2032. The first scenario (Current in Table 5) examined projections with the present state of fuel distributions. The second scenario (RPS in Table 5) explored the projections based on the fuel distributions, which are determined by the interpretation of current RPS goals. In the model, once total electricity generation is projected, either current or RPS based percent electricity projection is used to divide total electricity generation to estimate for each fuel type. Then, the electricity generation of each fuel type is converted to water consumption based on the consumption rate of each fuel type in each state. Therefore, the difference in water consumption between RPS and current scenarios provide estimates of water savings if the current portfolio of fuel types is changed from conventional to include higher percentage of solar energy, according to RPS.

Table 5. Percent electricity production for two scenarios to project water savings in each state

\begin{tabular}{ccccc}
\hline \multirow{2}{*}{ Scenario } & \multicolumn{4}{c}{ Percent Electricity Production } \\
\cline { 2 - 4 } & PV Solar & Coal & Natural Gas & Others \\
\hline \multicolumn{5}{c}{ Arizona } \\
\hline Current & $2.4 \%$ & $32.0 \%$ & $30.1 \%$ & $34.8 \%$ \\
RPS & $4.5 \%$ & $27.5 \%$ & $33.2 \%$ & $34.8 \%$ \\
\hline \multicolumn{5}{c}{ California } \\
\hline Current & $6.3 \%$ & $2.2 \%$ \\
RPS & $10.0 \%$ & $0.0 \%$ & $61.0 \%$ & $30.7 \%$ \\
\hline \multicolumn{5}{c}{ Nevada } \\
\hline Current & $4.0 \%$ & $6.9 \%$ & $40.0 \%$ \\
RPS & $4.0 \%$ & $2.0 \%$ & $72.4 \%$ \\
\hline \multicolumn{5}{c}{ New Mexico } \\
\hline Current & $1.9 \%$ & $62.8 \%$ & $16.4 \%$ \\
RPS & $4.0 \%$ & $58.8 \%$ & $28.5 \%$ \\
\hline \multicolumn{5}{c}{$30.2 \%$} \\
\hline Current & $0.08 \%$ & Utah & $7.0 \%$ \\
RPS & $1.0 \%$ & $74.3 \%$ & \\
\hline
\end{tabular}




\subsection{Statistical Analysis}

One-way analysis of variance (ANOVA) was used to study the differences in water use among the basin states. The Tukey's range test was used to compare the means for all five states using JMP software (SAS Institute Inc., Cary, NC, USA) and $p$ values $<0.05$, corresponding to a $95 \%$ confidence level, were considered significant. Significant differences are denoted by different capital letters in the figures.

\section{Results and Discussion}

\subsection{Total Water Usage by Thermal and PV Solar Power Plants}

Across the five study states over a 10-year period, 1954 operating generating units from 1508 utility scale power plants were assessed. Of these surveyed, generating units, geolocation, cooling systems, and prime mover type for 232 of the total operating units in the study were obtained from the literature.

A majority of the total generated thermoelectricity assessed came from two main fossil fuel energy sources: coal and petroleum products, and natural gas. As shown in Figure 3, generation of electricity by solar gradually started to increase in recent years. The linear regression trend line showed that a slight decrease in overall generation of electricity from 2005 to 2015 in all states, except for California. However, the $\mathrm{r}^{2}$ values were lower $\left(0.02<\mathrm{r}^{2}<0.39\right.$ depending on state) and the correlations were not significant $(p>0.05)$. Electricity that was generated by coal had decreasing trends in all five states and the linear correlations were significant $\left(p<0.05,0.52<\mathrm{r}^{2}<0.94\right)$, except for Arizona. On the other hand, electricity generated by natural gas had increasing trends in four states except Arizona in our study. The correlations in New Mexico, Nevada and Utah were significant $\left(p<0.05,0.48<\mathrm{r}^{2}<0.76\right)$, whereas it was insignificant in California $\left(p=0.16, \mathrm{r}^{2}=0.21\right)$. The substantially higher values of electricity generated in California when compared to the other basin states was due to the larger population, resulting in 13 times more power plants than in the other states. Furthermore, electricity generation in California showed a sharp increase in 2012. One of the possible causes for this shift could be due to the 30 newly commissioned natural gas generating units in 2012.

A current distribution of different fuel types of energy generation for each state in 2014 is provided in Figure 4. When the fuel types were arranged from most to least proactive on renewable energy adaptation, the basins states were ranked as follows; California, Arizona, Nevada, New Mexico, and Utah. Utah and New Mexico have the slowest adaptation to renewable energy when compared to the other states with more than 95 percent and 90 percent of the total electricity generation from coal and natural gas, respectively. As of 2014, Utah's electricity production from coal fuel is still at 76 percent of the state total. Even historical data for Nevada and Arizona's coal dependency in 1990 showed that they had a lower percentage than Utah's current record (75 percent for Nevada and 51 percent for Arizona). Generation of electricity from coal, petroleum, and natural gas in each state represented more than 60 percent of the total generation. Whereas, for all five states, solar energy facilities produced less than six percent of the total electricity generated. Nevada had the highest positive percent change over the last decade in adapting solar energy in general, with a 2.81 percent increase from 2005 to 2015. 

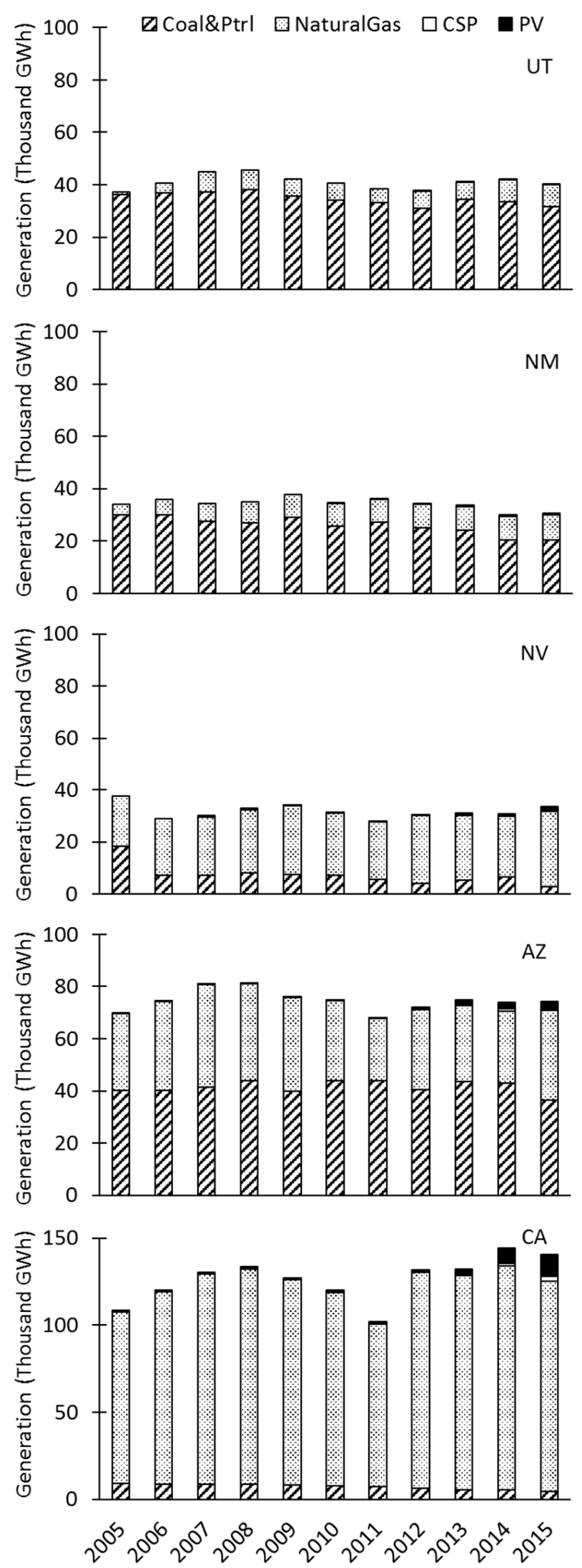

Figure 3. Electricity generation by fuel type in each state from 2005 to 2015 . Note that the range of $y$-axis for California is different from the other states. 


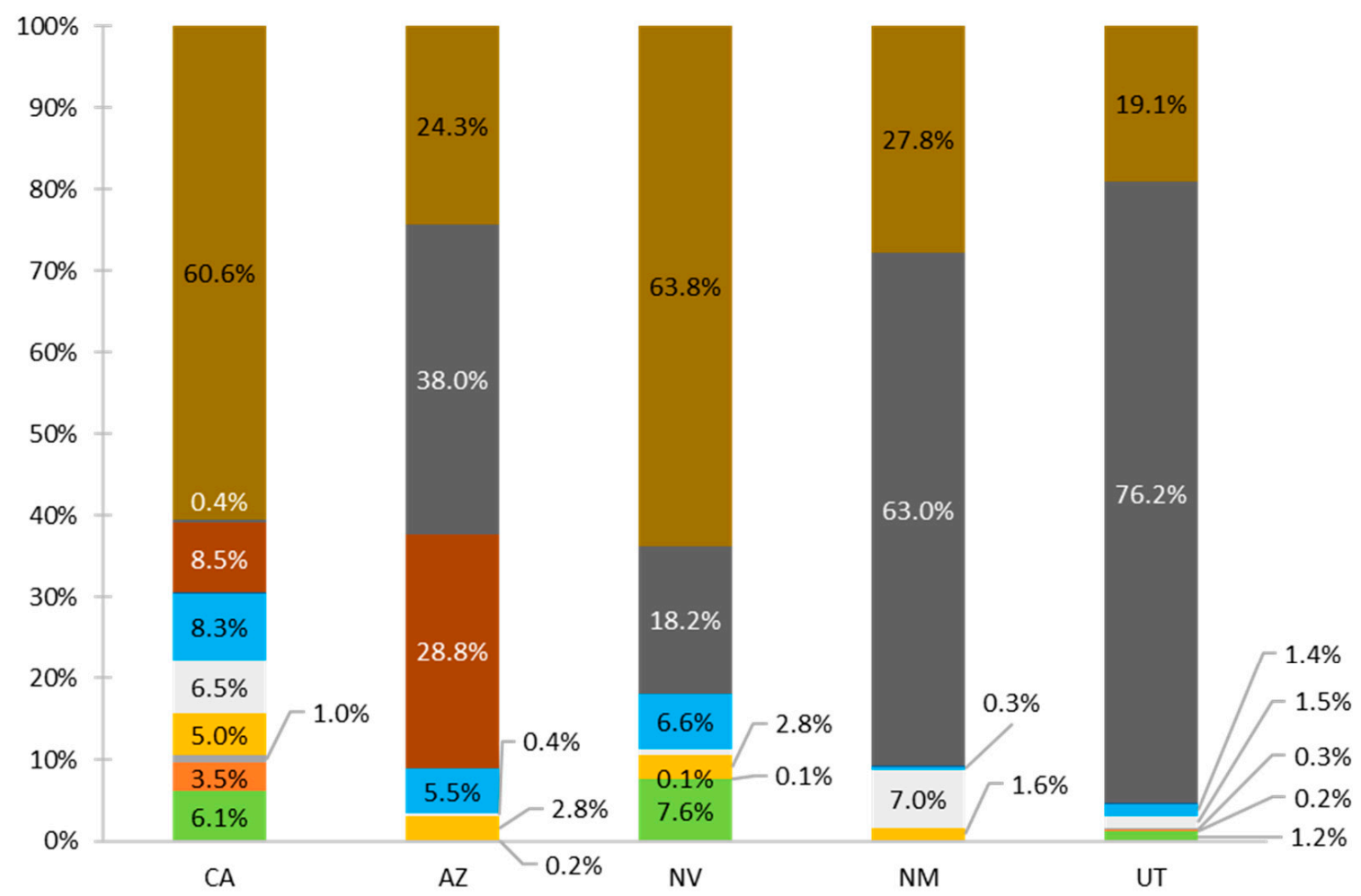

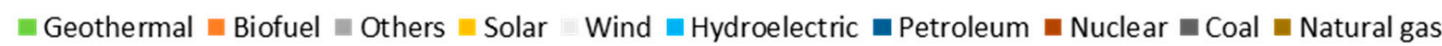

Figure 4. Percentage distribution of fuel types of electricity generation for each state in 2014 .

Figures 5 and 6 show total water consumption and withdrawal, respectively, by electricity generation for each state from 2005 to 2015. The total consumption was strongly correlated (linear regression) with the electricity generation $\left(\mathrm{r}^{2}=0.98, p<0.05\right)$. Overall, total withdrawal showed decreasing trend, especially in recent years.

The ratios of consumption to withdrawal in New Mexico, California, Arizona, Nevada, and Utah are $0.14,0.19,0.42,0.79$, and 0.80 , respectively, and they were statistically different $(p<0.05)$. The ratios in New Mexico and California were higher due to the cooling types that were used in the facilities. Cooling types largely affect the amount of water withdrawal and consumption. In New Mexico, a substantial amount of electricity is generated by the facilities generating electricity by coal with pond cooling system, which has much higher water withdrawal than water consumption. Similarly, in California, some of natural gas facilities use once through cooling systems that also increase the amount of water withdrawal.

Figure 7 shows the average water withdrawal and consumption rates for different fuel types in each state. Average water withdrawal rate for coal power plants ranged from $4.05 \mathrm{~L} / \mathrm{kWh}$ in Nevada and Utah to $25.97 \mathrm{~L} / \mathrm{kWh}$ in New Mexico, whereas the rate of natural gas power plants ranged from $1.70 \mathrm{~L} / \mathrm{kWh}$ in Utah to $16.39 \mathrm{~L} / \mathrm{kWh}$ in California. Average water consumption rate for coal power plants ranged from $2.76 \mathrm{~L} / \mathrm{kWh}$ in New Mexico to $3.03 \mathrm{~L} / \mathrm{kWh}$ in Nevada, whereas the rate for natural gas power plants ranged from $1.97 \mathrm{~L} / \mathrm{kWh}$ in Nevada to $3.29 \mathrm{~L} / \mathrm{kWh}$ in Arizona. Note that both water consumption and water withdrawal rates for natural gas could be higher than those for coal power plants in some states. 

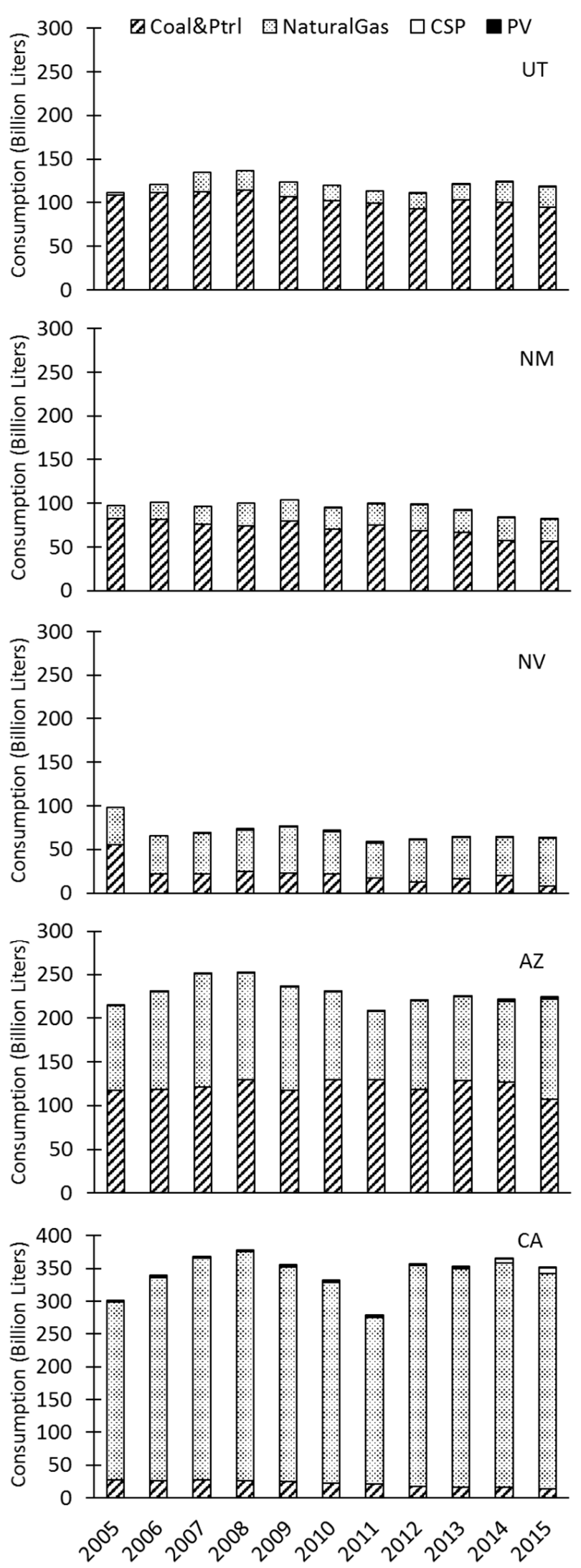

Figure 5. Total water consumption by electricity generation for each state from 2005 to 2015 . Note that the range of $y$-axis for California is different from the other states. 

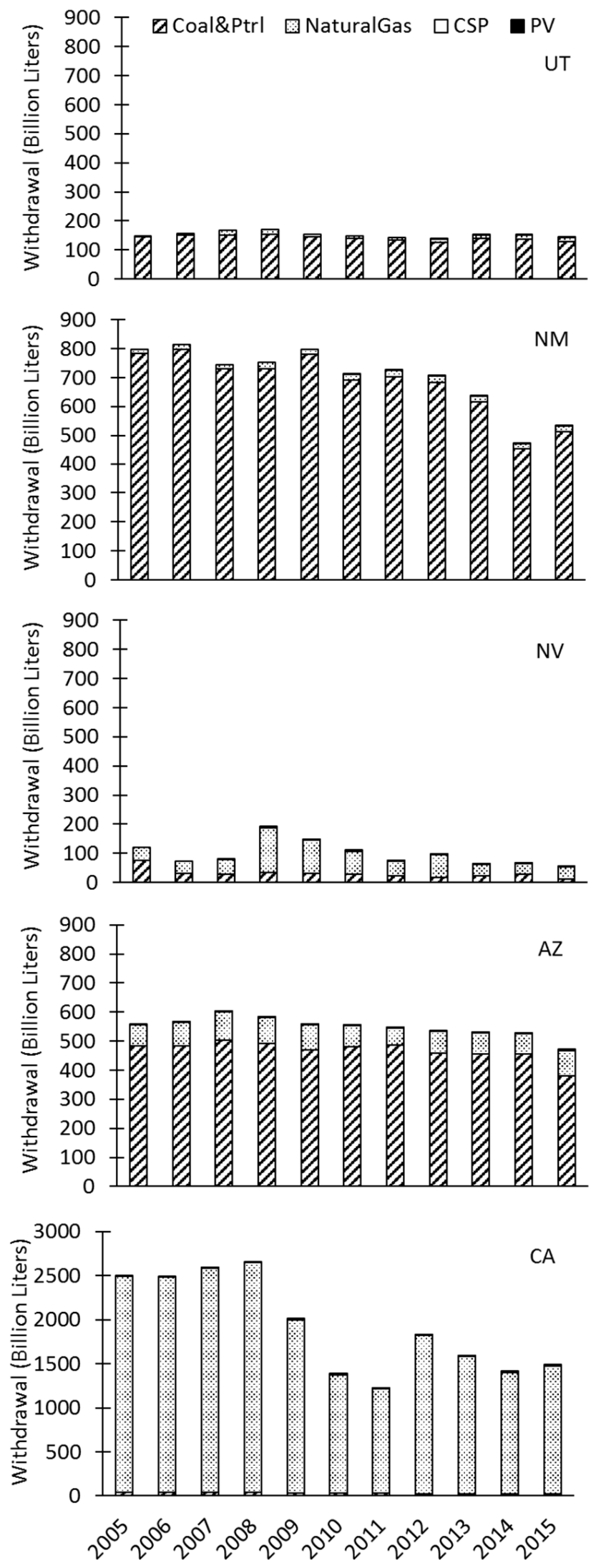

Figure 6. Total water withdrawal by electricity generation for each state from 2005 to 2015 . Note that the range of $y$-axis for California is different from the other states. 

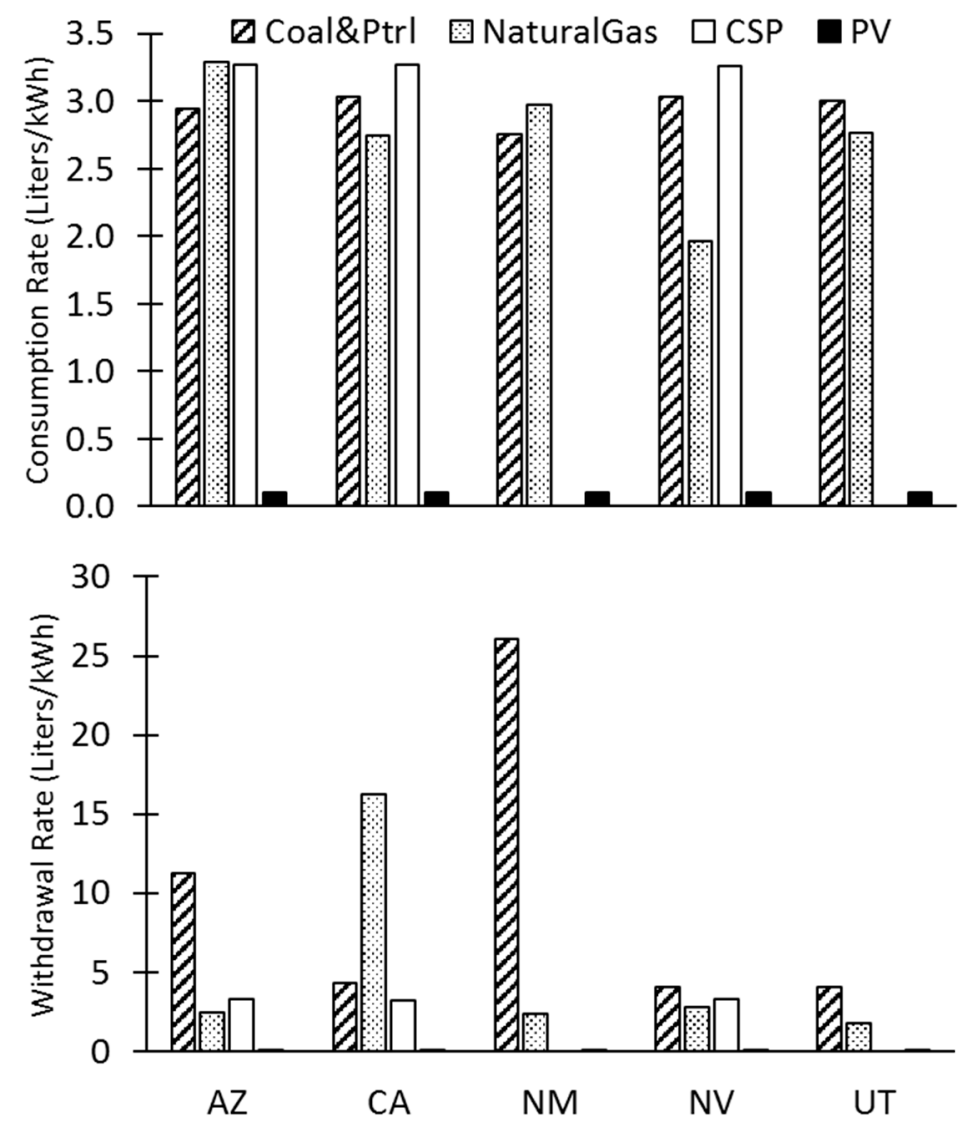

Figure 7. Average water consumption rate (top) and withdrawal rate (bottom) for different fuel type power plants in each state.

Figure 8 shows normalized average total water consumption and withdrawal for electricity generation by number of households between 2005 and 2015. California had the lowest water consumption of about 9.1 thousand liters. On the other hand, New Mexico had the highest water consumption of about 46.9 thousand liters followed by Utah (about 43.9 thousand liters), Arizona (about 35.2 thousand liters), and Nevada (about 25.7 thousand liters). Statistical analysis showed that water consumption per capita among the basin states was significantly different from each other except in the case of New Mexico and Utah. For the normalized water withdrawal, Nevada had the lowest water withdrawal (about 36.0 thousand liters), closely followed by California (about 51.5 thousand liters), Utah (about 54.9 thousand liters), and Arizona (about 84.4 thousand liters). New Mexico had the highest water withdrawal with a large difference from the other states (about 346.0 thousand liters). The situation in New Mexico may have been due to a higher percentage of electricity generation by coal and higher average withdrawal rate for those coal power plants. Average withdrawal rate for coal power plants in New Mexico was $26.1 \mathrm{~L} / \mathrm{kWh}$, whereas the second highest withdrawal rate for coal power plants was in Arizona, with $11.4 \mathrm{~L} / \mathrm{kWh}$ (Figure 5).

On average, Arizona had the highest annual household electricity use rate of $12,732 \mathrm{kWh}$, whereas California had the lowest, $6444 \mathrm{kWh}$ [29]. However, Arizona was not the highest in water consumption and withdrawal among the five states in our study. California had the lowest water consumption rate, but not the lowest water withdrawal. This implies that water usage is affected not only by electricity usage, but also by the type of power plants generating electricity. The difference in water usage depending on the type of power generation plant was also reported in [30]. 

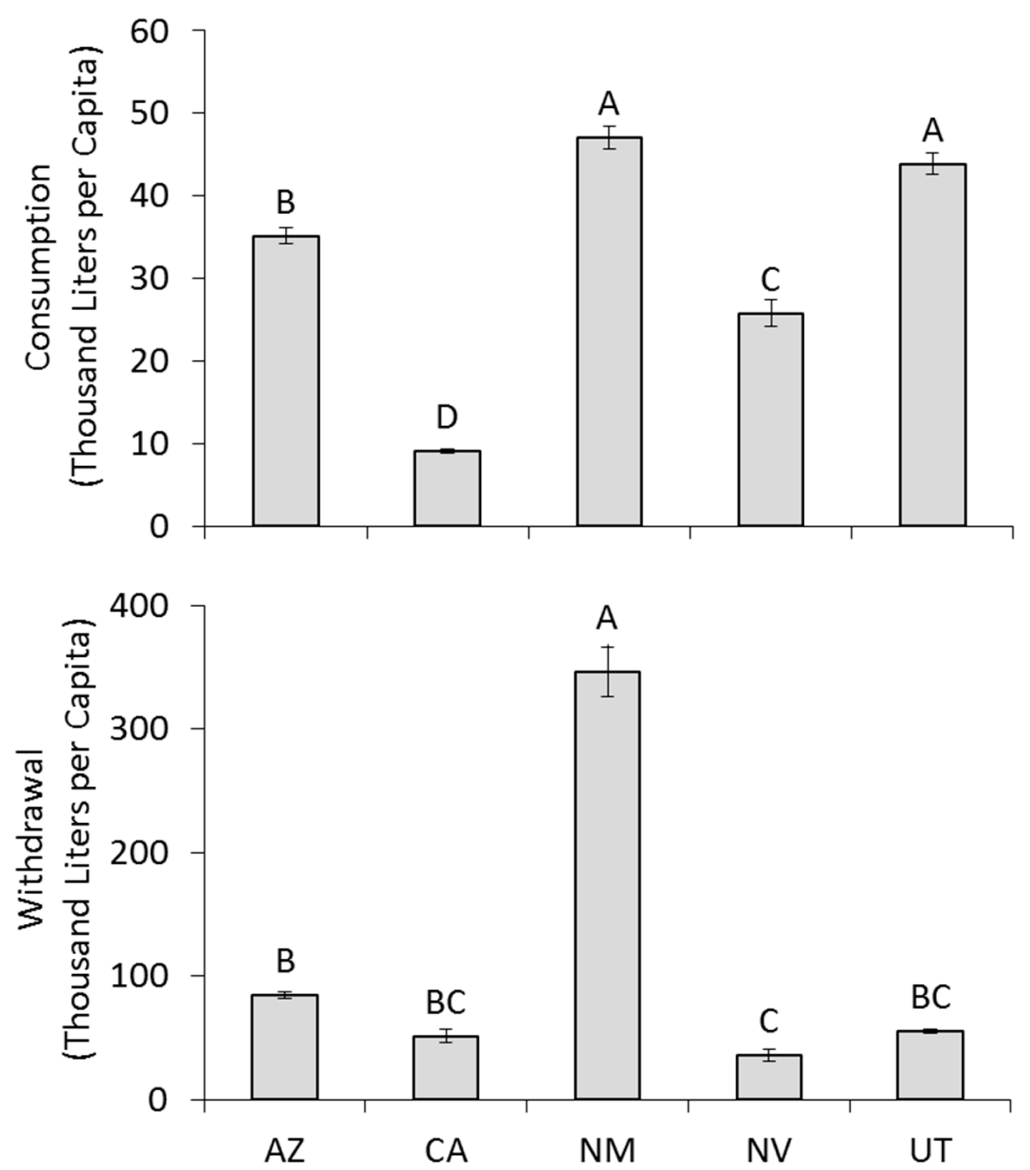

Figure 8. Average water consumption (top) and withdrawal (bottom) for electricity generation per capita between 2005 and 2015 for each state. Capital letters (A, B, C, and D) above bars represent results of pair-wise comparison (Tukey HSD) test. Error bars are one standard error.

\subsection{Future Water Usage}

The amount of electricity projected to be used in the Colorado River Basin states from 2015 to 2040 is shown in Table 6. According to EIA energy outlook [21], electricity usage will increase as population increases, but at a substantially slower pace than observed between 2000 and 2015. Some of the reasons for slower growth may be effects of increased energy-efficient housing and newer energy regulations. Projected populations in all five states have increasing trends with California's population increasing the fastest among the basin states (Table 7). Utah is projected to have higher electricity usage per capita, based on the projected electricity demand and the projected population growth, than the other states.

Table 6. Forecast of electricity demand based on Energy Information Administration (EIA) estimated annual growth rate. Unit is in GWh.

\begin{tabular}{cccccc}
\hline Year & AZ & CA & NM & NV & UT \\
\hline 2020 & 112,456 & 211,909 & 36,502 & 36,813 & 43,174 \\
2025 & 112,478 & 211,951 & 36,509 & 36,820 & 43,183 \\
2030 & 114,148 & 215,098 & 37,051 & 37,367 & 43,824 \\
2035 & 115,262 & 217,197 & 37,412 & 37,731 & 44,252 \\
2040 & 116,376 & 219,295 & 37,774 & 38,096 & 44,679 \\
\hline
\end{tabular}


Table 7. Projected populations.

\begin{tabular}{cccccc}
\hline Year & AZ & CA & NM & NV & UT \\
\hline 2020 & $7,901,618$ & $41,660,673$ & $2,544,804$ & $3,140,610$ & $3,277,625$ \\
2025 & $8,738,145$ & $44,020,206$ & $2,730,823$ & $3,360,623$ & $3,486,943$ \\
2030 & $9,624,155$ & $45,265,231$ & $2,974,730$ & $3,584,147$ & $3,851,448$ \\
2035 & $10,333,574$ & $45,747,645$ & $3,196,809$ & $5,172,068$ & $4,095,877$ \\
2040 & $11,361,331$ & $47,233,240$ & $3,435,468$ & $5,822,749$ & $4,499,657$ \\
\hline
\end{tabular}

Table 8 shows the projected water consumption for each scenario in all five basin states in 2015, 2022, and 2032. Annual water saving in Table 8 projects how much water can be saved during that year if electricity was generated with the RPS fuel distribution scenario instead of the current fuel distribution scenario. In all states, electric generation is projected to increase over time, resulting in the greatest water savings in 2032. However, the amount of water saved is different for each state. California's electricity generation by PV solar is projected to increase, while electricity generation by coal is predicted to remain at zero under the RSP scenario. California generates the largest amount of electricity among the five states, as such, they will save more than 62 billion liters of water in 2032 if the RPS scenario is achieved. On the other hand, Arizona, which is the second highest electricity generating state, is projected to save only a small amount of water (6.7 billion liters of water in 2032) when compared to California. Even though Arizona is projected to decrease electricity generation by coal, the replacement is expected to occur from both PV solar and natural gas. In Arizona, power plants operating with natural gas have a higher water consumption rate than that of power plants operated with coal. Therefore, even though an increase in PV solar will help to save water, the savings will not be large. Similar is the case for New Mexico. New Mexico is also replacing coal with PV solar and natural gas. However, water saving is projected to be only 2.7 billion liters in 2032. In contrast to New Mexico, Nevada, whose annual electricity generation is close to that of New Mexico, is projected to save 4.9 billion liters of water in 2032 by replacing coal with natural gas, associated with a large difference in the water consumption rate between coal and natural gas. Since Utah's RPS was closest to continuing the current conditions, water savings are projected to be the lowest among the five states and expected to be only 1.2 billion liters of water in 2032 .

In this study, future water consumption for energy generation was estimated by assuming that it predominantly depends on the population growth. Therefore, factors such as regional climate change and the duration of wet and dry years were assumed to be less impactful on water consumption for electricity generation. However, the data reported in [31] showed that substantial changes in cooling water use as a result of climate change. Furthermore, in our model, the generating unit characteristics (i.e., type of cooling systems and technologies) within each power plant were assumed to remain the same. Cooling system and type of technology affects water consumption, as reflected in the withdrawal rates $[14,16,18]$. As reported in [32], oil and gas drilling and production are expected to increase in coming years, which can alter the distribution of electricity generation for each fuel type. New technologies such as electric cars and improved energy efficiency may also affect the amount of the electricity generation, which may lead to changes in water usage. There are many factors that can directly and indirectly lead to changes in future electricity generation and water uses which are not currently included in our model. The current study only focusses on the impact of population and redistribution of energy production types to meet states' RPS goals and corresponding water uses. Our results include certain limitations on interpreting the water usage. However, the study helps to shed light on water resource management involving the utility scale energy sector. 
Table 8. Projected water consumption and annual water savings in 2015, 2022 and 2032 for each state.

\begin{tabular}{|c|c|c|c|c|c|c|}
\hline \multirow{2}{*}{ Year } & \multirow{2}{*}{ Scenario } & \multicolumn{4}{|c|}{ Water Consumption (Million Liters/Year) } & \multirow{2}{*}{$\begin{array}{l}\text { Annual Water Saving } \\
\text { (Million Liters/Year) }\end{array}$} \\
\hline & & PV Solar & Coal & Natural Gas & Total & \\
\hline \multicolumn{7}{|c|}{ Arizona } \\
\hline \multirow{2}{*}{2015} & Current & 269 & 92,920 & 74,732 & 167,921 & \\
\hline & RPS & 503 & 79,853 & 82,431 & 162,788 & 5133 \\
\hline \multirow[b]{2}{*}{2022} & Current & 299 & 103,433 & 83,188 & 186,920 & \\
\hline & RPS & 560 & 88,889 & 91,755 & 181,204 & 5716 \\
\hline \multirow{2}{*}{2032} & Current & 352 & 122,000 & 98,122 & 220,474 & \\
\hline & RPS & 662 & 104,845 & 108,229 & 213,736 & 6738 \\
\hline \multicolumn{7}{|c|}{ California } \\
\hline \multirow[b]{2}{*}{2015} & Current & 1257 & 11,754 & 201,834 & 214,845 & \\
\hline & RPS & 1995 & 0 & 165,438 & 167,432 & 47,412 \\
\hline \multirow{2}{*}{2022} & Current & 1408 & 13,158 & 225,955 & 240,521 & \\
\hline & RPS & 2233 & 0 & 185,209 & 187,442 & 53,079 \\
\hline \multirow{2}{*}{2032} & Current & 1658 & 15,509 & 266,319 & 283,486 & \\
\hline & RPS & 2635 & 0 & 218,297 & 220,932 & 62,554 \\
\hline \multicolumn{7}{|c|}{ Nevada } \\
\hline \multirow{2}{*}{2015} & Current & 129 & 24,908 & 7298 & 32,335 & \\
\hline & RPS & 129 & 25,733 & 2116 & 27,978 & 4357 \\
\hline \multirow{2}{*}{2022} & Current & 136 & 26,131 & 7654 & 33,921 & \\
\hline & RPS & 136 & 26,998 & 2218 & 29,352 & 4569 \\
\hline \multirow{2}{*}{2032} & Current & 148 & 28,190 & 8260 & 36,597 & \\
\hline & RPS & 148 & 29,125 & 2392 & 31,665 & 4932 \\
\hline \multicolumn{7}{|c|}{ New Mexico } \\
\hline \multirow{2}{*}{2015} & Current & 34 & 49,112 & 17,765 & 66,911 & \\
\hline & RPS & 72 & 45,981 & 18,825 & 64,878 & 2033 \\
\hline \multirow[b]{2}{*}{2022} & Current & 38 & 54,408 & 19,680 & 74,126 & \\
\hline & RPS & 79 & 50,940 & 20,854 & 71,874 & 2252 \\
\hline \multirow{2}{*}{2032} & Current & 45 & 65,435 & 23,670 & 89,150 & \\
\hline & RPS & 95 & 61,267 & 25,082 & 86,444 & 2707 \\
\hline \multicolumn{7}{|c|}{ Utah } \\
\hline \multirow{2}{*}{2015} & Current & 0 & 82,825 & 13,510 & 96,335 & \\
\hline & RPS & 15 & 81,723 & 13,510 & 95,248 & 1086 \\
\hline \multirow{2}{*}{2022} & Current & 0 & 86,860 & 14,165 & 101,025 & \\
\hline & RPS & 15 & 85,705 & 14,165 & 99,886 & 1139 \\
\hline \multirow[b]{2}{*}{2032} & Current & 0 & 93,628 & 15,270 & 108,899 & \\
\hline & RPS & 19 & 92,383 & 15,270 & 107,672 & 1226 \\
\hline
\end{tabular}

\section{Conclusions}

Although implementing an RPS for each state may not have been done for the reason of water conservation, our simulation results show that it leads to significant water savings. Water can be saved by replacing the generation of thermal electricity with the generation of PV solar electricity. However, the amount of water saved varied significantly depending on the state's choice of coal or natural gas. Arizona and New Mexico are projected to save more water by replacing natural gas with PV solar, whereas the other basin states will save more water by replacing coal with PV solar. Furthermore, some of the lower water consuming power plants may have higher water withdrawal rates. Even though some of the water withdrawn will eventually be returned to its source, the amount 
of water withdrawal was shown to be much larger than the amount of water consumption in all five states. This study clearly showed that achieving an RPS will save water in all five basin states, even though the amount saved will be substantially different depending on how vigorously states pursue replacement of thermal electric generation with less water intensive alternatives, such as PV solar.

Acknowledgments: The authors would like to acknowledge Crystal Dubose for her contribution to technological support.

Author Contributions: Yuzhen Feng and Sachiko Sueki conducted data collection, analysis and drafting of manuscript. Dale Devitt and Kumud Acharya designed, guided and supervised the research, and contributed in finalizing manuscript.

Conflicts of Interest: The authors declare no conflict of interest.

\section{References}

1. Benke, C.; Cushing, C.E. Colorado river basin. In Rivers of North America; Blinn, D.W., Poff, N.L., Eds.; Elsevier Academic Press: Burlington, MA, USA, 2005; pp. 482-538. ISBN 0-12-088253-1.

2. Maupin, M.A.; Kenny, J.F.; Hutson, S.S.; Lovelace, J.K.; Barber, N.L.; Linsey, K.S. Estimated Use of Water in the United States in 2010. U.S. Geological Survey Circular 1405. Available online: http:/ /dx.doi.org/10. 3133/cir1405 (accessed on 18 February 2018).

3. Lustgarten, A. Use It or Lose It Laws Worsen Western U.S. Water Woes. Scientific American 2017. Available online: https:/ / www.scientificamerican.com/article/use-it-or-lose-it-laws-worsen-western-u-s-waterwoes/ (accessed on 19 February 2018).

4. Tory, S. Money for Water: A Pilot Project Wins over Skeptical Farmers and Ranchers. Aspen Journalism 2017. Available online: https:/ / www.aspenjournalism.org/2017/08/30/money-for-water-a-pilot-project-winsover-skeptical-farmers-and-ranchers / (accessed on 19 February 2018).

5. Williams, A.P.; Seager, R.; Berkelhammer, M.; Macalady, A.K.; Crimmins, M.A.; Swetnam, T.W.; Rahn, T. Causes and implications of extreme atmospheric moisture demand during the record-breaking 2011 wildfire season in the southwestern United States. J. Appl. Meteorol. Climatol. 2014, 53, 2671-2684. [CrossRef]

6. Kearney, M.S.; Harris, B.H.; Hershbein, B.; Jácome, E.; Nantz, G. In Times of Drought: Nine Economic Facts about Water in the United States. The Hamilton Project. Available online: http:/ / www.hamiltonproject.org/ files/downloads_and_links/nine_economic_facts_about_us_water_final.pdf (accessed on 18 February 2018).

7. U.S. Census Bureau. The 10 Fastest-Growing States from 2013 to 1 July 2014; Release No. CB14-232; U.S. Census Newsroom: Washington, DC, USA, 2014. Available online: http://www.census.gov/newsroom/pressreleases/2014/cb14-232.html (accessed on 18 February 2018).

8. MacDonald, G.M. Water, climate change, and sustainability in the southwest. Proc. Natl. Acad. Sci. USA 2010, 107, 21256-21262. [CrossRef] [PubMed]

9. Thiel, A. Climate Change Impacts on Hydropower in the Colorado River Basin. Center for Water Policy. Available online: http:/ / uwm.edu/centerforwaterpolicy/wp-content/uploads/sites/170/2013/ 10/Colorado_Energy_Final.pdf (accessed on 18 February 2018).

10. Capehart, M. Drought Diminishes Hydropower Capacity in Western U.S. Water Resources Research Center. Available online: https://wrrc.arizona.edu/drought-diminishes-hydropower (accessed on 18 February 2018).

11. Dineen, C. Drought and California's role in the Colorado River compact. J. Legis. 2016, 42, 211-231.

12. Xia, R. Drought Cuts Power Production of California Dams. Los Angeles Times. Available online: http: / / www.latimes.com/local/ california /la-me-drought-hydro-20150517-story.html\#page=1 (accessed on 18 February 2018).

13. Southwestern Water Conservation District, 2015 Annual Water Seminar Presentations. Available online: http:/ / swwcd.org/programs/annual-water-seminar (accessed on 18 February 2018).

14. Macknick, J.; Newmark, R.; Heath, G.; Hallett, K.C. A Review of Operational Consumption and Withdrawal Factors for Electricity Generating Technologies; National Renewable Energy Laboratory Technical Report; NREL/TP-6A20-50900; National Renewable Energy Laboratory: Golden, CO, USA, 2011.

15. U.S. Department of Energy, Energy Information Administration. Form EIA-860: Annual Electric Generator Report. Available online: https:/ / www.eia.gov/electricity/data/eia860/ (accessed on 18 February 2018). 
16. Fthenakis, V.; Kim, H.C. Life-cycle uses of water in U.S. electricity generation. Renew. Sustain. Energy Rev. 2010, 14, 2039-2048. [CrossRef]

17. Averyt, K.; Macknick, J.; Rogers, J.; Madden, N.; Fisher, J.; Meldrum, J.; Newmark, R. Water use for electricity in the United States: An analysis of reported and calculated water use information for 2008. Environ. Res. Lett. 2013, 8, 015001. [CrossRef]

18. Diehl, T.H.; Harris, M.A.; Murphy, J.C.; Hutson, S.S.; Ladd, D.E. Methods for Estimating Water Consumption for Thermoelectric Power Plants in the United States; U.S. Geological Survey Scientific Investigations Report 2013-5188; U.S. Geological Survey: Reston, VA, USA, 2013.

19. U.S. Department of Energy; Energy Information Administration. Form EIA-923: Detailed Electric Power Data; Power Plant Operations Report; U.S. Department of Energy: Washington, DC, USA, 2015.

20. Mackun, P.; Wilson, S. Population Distribution and Change: 2000 to 2010. 2010 Census Briefs. C2010BR-01. Available online: https:/ / www.census.gov/prod/cen2010/briefs/c2010br-01.pdf (accessed on 18 February 2018).

21. U.S. Department of Energy, Energy Information Administration. Annual Energy Outlook 2016 with Projections to 2040. Available online: https:/ / www.eia.gov/outlooks/aeo/pdf/0383(2016).pdf (accessed on 18 February 2018).

22. Renewable Portfolio Standard (RPS). Renewable Energy Standard \& Tariff for Arizona. Decision No. 69127. 2006. Available online: http://www.azcc.gov/divisions/utilities/electric/environmental.asp (accessed on 18 February 2018).

23. Renewable Portfolio Standard (RPS). California Renewables Portfolio Standard Program. California Public Utilities Article 16, Code Section 399.11-399.32. 2007. Available online: https:/ / leginfo.legislature.ca.gov / faces $/$ codes_displayText.xhtml?lawCode=PUC\&division=1.\&title=\&part=1.\&chapter=2.3.\&article=16 (accessed on 18 February 2018).

24. Renewable Portfolio Standard (RPS). RPS Program Overview, California Public Utilities Commission. 2018. Available online: http:/ / www.cpuc.ca.gov/RPS_Overview/ (accessed on 18 February 2018).

25. Renewable Portfolio Standard (RPS). New Mexico Renewable Energy Act in Utility Renewable Energy Public Regulation Commission. 1978. Available online: http:/ /www.nmprc.state.nm.us/utilities/renewableenergy.html (accessed on 18 February 2018).

26. Renewable Portfolio Standard (RPS). Nevada Renewable Portfolio Standard. NRS $704.7311-7322$ : Reduction of Emissions from Coal-Fired Electric Generating Plants. 1997. Available online: https:/ /www.leg.state.nv. us/NRS/NRS-704.html\#NRS704Sec7311 (accessed on 18 February 2018).

27. Renewable Portfolio Standard (RPS). NV RPS: Source 2: Nevada Renewable Portfolio Standard. NRS 704.7801-7828: Establishment of Portfolio Standard; Requirements; Treatment of Certain Solar Energy Systems; Portfolio Energy Credits; Renewable Energy Contracts and Energy Efficiency Contracts; Exemptions; Regulations. 1997. Available online: http://www.leg.state.nv.us/Nrs/NRS-704.html\# NRS704Sec7801 (accessed on 18 February 2018).

28. Renewable Portfolio Standard (RPS). Utah energy resource procurement act. In Code Title 54-17-602; Utah State Legislature: Salt Lake, UT, USA, 2005. Available online: http://le.utah.gov/xcode/Title54/ Chapter17/C54-17_1800010118000101.pdf (accessed on 18 February 2018).

29. U.S. Department of Energy; Energy Information Administration. State Profiles and Energy Estimates in 2014. Available online: http:/ / www.eia.gov / state/ (accessed on 18 February 2018).

30. Smith, A.D.; Omitaomu, O.A.; Peck, J.J. Modeling the impacts of solar distributed generation on U.S. water resources. In Proceedings of the ASME 2015 Power and Energy Conversion Conference, San Diego, CA, USA, 28 June-2 July 2015.

31. Peck, J.J.; Smith, A.D. Modeling power generation water usage. In Proceedings of the ASME 2015 Power and Energy Conversion Conference, San Diego, CA, USA, 28 June-2 July 2015.

32. Zborowski, M. US rig count drops again, but drilling growth still seen. Oil Gas J. 2017. Available online: http: / / www.ogj.com/articles/2017/10/us-rig-count-drops-again-but-drilling-growth-still-seen.html (accessed on 18 February 2018).

(C) 2018 by the authors. Licensee MDPI, Basel, Switzerland. This article is an open access article distributed under the terms and conditions of the Creative Commons Attribution (CC BY) license (http:/ / creativecommons.org/licenses/by/4.0/). 